\title{
A New Frontier in the Law of the Sea? Responding to the Implications of Sea Level Rise for Baselines, Limits and Boundaries
}

\author{
Clive Schofield
}

There is now scant doubt in the scientific community that global mean sea levels are rising and will continue to do so during the remainder of the $21^{\text {st }}$ century and beyond. ${ }^{1}$ Considerable uncertainties persist, however, regarding key concerns such as the magnitude and rate of contributions from the cryosphere, especially ice-sheets, and spatially in terms of regional distribution of sea level rise. ${ }^{2}$ This has raised concerns over the potential inundation and erosion of lowlying coasts, including islands, around the world. ${ }^{3}$ Professor David Freestone was among the earliest of international legal commentators to identify related threats to the location of baselines along the coast and therefore on the scope of national claims to maritime jurisdiction as well as on the delimitation of maritime boundaries. ${ }^{4}$ This pioneering legal scholarship regarding the issues posed

1 The Intergovernmental Panel on Climate Change (IPCC) Fifth Assessment Report (AR5) considers this to be 'virtually certain'. See, Chapter 13, 'Sea Level change' in IPCC, Climate Change 2013: The Physical Science Basis. Contribution of Working Group I to the Fifth Assessment Report of the Intergovernmental Panel on Climate Change (Cambridge University Press, 2013) 11371205, 1205, http://www.climatechange2013.org/images/report/WG1AR5_ALL_FINAL.pdf; accessed 27 June 2019 .

2 Ibid.

3 A summary of the key challenges posed by sea level rise is provided in D Freestone, D Vidas and A Torres Camprubí, 'Sea Level Rise and Impacts on Maritime Zones and Limits: The Work of the ILA Committee on Sea Level Rise and International Law' (2017) 3 Korean Journal of International and Comparative Law $5^{-35}$.

4 See, for example, D Freestone and JS Pethick, 'International Legal Implications of Coastal Adjustments under Sea Level Rise: Active or Passive Policy Responses?' in UnEP/Wmo/ USACE/EPA/NOAA, Changing Climate and the Coast. Report to the Intergovernmental Panel on Climate Change from the Miami Conference on Adaptive Responses to Sea Level Rise and Other Impacts of Global Climate Change, Vol 1(1990) 237-256; D Freestone, 'International Law and Sea Level Rise' in RR Churchill and D Freestone (eds), International Law and Global Climate Change (Graham and Trotman/Martinus Nijhoff, 1991) 109-125; D Freestone and J Pethick, 'Sea Level Rise and Maritime Boundaries: International Implications of Impacts and 
by sea level rise in the context of the law of the sea as well as some of the response options open to coastal States will be reviewed as it has enduring relevance to contemporary debates on this increasingly pressing issue.

This chapter outlines the evolution of scientific understanding and projections of sea level rise while acknowledging the considerable associated complexities and uncertainties, especially in terms of applying global projections to specific coastal situations. Discussion then turns to the implications of sea level rise for maritime claims and the evolving practice of States in response to this threat. This area of the law of the sea is evolving progressively. To address the need for greater stability and certainty in baselines, maritime limits and boundaries a substantial change in the interpretation of aspects of the international law of the sea will be required, the 'new frontier' alluded to in the chapter title.

This is a frontier issue that recognizes the vulnerability of coasts, islands and even entire island States to the threat of sea level rise. Moreover, this phenomenon challenges established understandings of law of the sea leading to fresh approaches with the potential to change existing norms. Indeed, such changes are arguably already under way and, again, Freestone is at the forefront of this progressive evolution of the international law of the sea, notably through his work as co-rapporteur of the International Law Association's (ILA) Committee on International Law and Sea Level Rise. ${ }^{5}$ The chapter concludes with some considerations on the relative merits, and demerits, of these potentially significant changes in the international law of the sea fundamentally related to the scope of maritime claims.

\section{Disappearing Coasts}

It has long been recognized that coasts are dynamic and change or fluctuate in location over time. ${ }^{6}$ Coastal changes can occur through a number of processes, notably through natural depositional and alluvial processes that serve to advance coastlines such as deltas around the world. Coastlines may also incrementally advance thanks to isostatic (or post-glacial) adjustment whereby

Responses' in G Blake (ed.), International Boundaries; Fresh Perspectives, Vol 5 (Routledge, 1994) 73-9o.

5 See Freestone, Vidas and Torres Camprubí, above (n 3). The present author is also a Member of the Committee.

6 See generally, CD Woodroffe, Coasts: Form Process and Evolution (Cambridge University Press, 2003) 1-2. See also, W Hirst and D Robertson, 'Geographic Information Systems, Charts and UNCLOS: Can They Live Together?' (May-June 2004) 136 Maritime Studies 1-6. 
the continental crust is gradually rising following the removal of the enormous weight of major ice-sheets, some several kilometres thick, after the end of the last ice-age. ${ }^{7}$ Although rates of uplift as a result of isostatic rebound are generally thought to be of the order of $1 \mathrm{~cm}$ or less, even this seemingly slight rise can have significant consequences in the context of low-lying, shallow gradient coastlines. For example, Canada's Hudson's Bay region is understood to be experiencing uplift at a rate of approximately 60 centimetres per century, something which means that Canada is 'steadily gaining many hundred square kilometres of territory each year.'

Similarly, volcanic or tectonic activity can also lead to the emergence of additional land, and therefore coasts, above the surface of the sea. For example, the island of Surtsey, located approximately $17 \mathrm{~nm}(32 \mathrm{~km})$ south of Iceland, emerged as a result of volcanic eruptions between 1963 and $1967 . .^{9}$ Similarly, it has been estimated that Australia's sub-Antarctic McDonald Island approximately doubled in size (to $2.45 \mathrm{~km}^{2}$ ) as a result of a series of volcanic eruptions in $1996-1997 .^{10}$ Further, coastlines can advance dramatically through reclamation projects. Perhaps the best example of this is provided by Singapore which has increased its land area from $581.5 \mathrm{~km}^{2}$ to $710 \mathrm{~km}^{2}$ as a result of sustained and large-scale land reclamation projects. ${ }^{11}$ The counterpoint is that

Note that in other areas, such as those located on the margins of major ice sheets, post-glacial readjustment results in a decrease in elevation as the Earth's mantle settles. See JM Johansson, JL Davis, H-G Scherneck et al., 'Continuous GPS Measurements of Postglacial Adjustment in Fennoscandia. 1 Geodetic results' (2002) 107 Journal of Geophysical Research B8.

8 See JH Marsh, 'Hudson Bay', The Canadian Encyclopedia, https://www.thecanadianencyclopedia.ca/en/article/hudson-bay; accessed 27 June 2019; see also, International Hydrographic Organization (IHO) (with the International Oceanographic Commission and the International Association of Geodesy), A Manual on Technical Aspects of the United Nations Convention on the Law of the Sea, 1982, Special Publication No 51 (4th edition, International Hydrographic Bureau, 2006) ch 2, 16-17. This publication is often referred to as the 'TALOS Manual'.

The island has been protected since it was formed and has been included in the United Nations Educational, Scientific and Cultural Organization (UNESCO) World Heritage List since 2008. See. UnEsco, 'Surtsey', World Heritage List, https://whc.unesco.org/en/list/ 1267/; accessed 27 August 2019.

10 See, Geoscience Australia, 'Heard and McDonald Islands', https://www.ga.gov.au/ scientific-topics/national-location-information/dimensions/remote-offshore-territories/ heard-and-mcdonald-islands; accessed 27 August 2019. See also, WL Gullett and CH Schofield, 'Pushing the Limits of the Law of the Sea Convention: Australian and French Cooperative Surveillance and Enforcement in the Southern Ocean' (2007) 22(4) International Journal of Marine and Coastal Law 545-583, 545 and 562-563; M McCarthy, 'Australia's Heard Island: A Mysterious Land of Ice and Fire' ABC News (25 January 2019), https://www.abc.net.au/news/2019-01-25/heard-island-australias-mysterious-land-offire-and-ice/1071386o; accessed 27 August 2019.

11 See C Milton, 'The Sand Smugglers' Foreign Policy (4 August 2010), http://www.foreignpolicy.com/articles/2010/o8/o4/the_sand_smugglers; accessed 27 June 2019). 
just as coasts can advance, so they can retreat. For example, 'ephemeral features' including low-elevation islands and low-tide elevations in delta contexts such as that of the Ganges-Brahmaputra may repeatedly appear and disappear cyclically, for instance on a seasonal basis. ${ }^{12}$ Similarly, newly emerged volcanic islands may be subject to substantial settlement, erosion and potential disappearance. ${ }^{13}$ Traditionally, this has taken place as a result of natural erosional processes within the context of an era when sea level was understood, or at least assumed by many, to be essentially stable.

The fundamental challenge now is that as a result of anthropogenicallyinduced significant and accelerating global sea level rise, coastlines and coastal ecosystems are not changing merely through natural processes alone. This raises the prospect of potentially significant inundation and thus, essentially, disappearing coasts, including the potential for the complete submergence or disappearance of low-elevation islands.

The contribution of ice to global sea level, known as 'glacial theory,', ${ }^{14}$ was widely accepted in the scientific community by the end of the nineteenth century and is well supported by evidence from marine deposits at higher elevations than present sea level. ${ }^{15}$ Since that time numerous techniques have been applied by scientists to establish that sea levels have been radically different over geological time scales. ${ }^{16}$

12 CH Schofield, 'Shifting Limits?: Sea Level Rise and Options to Secure Maritime Jurisdictional Claims'(2009) 4 Carbon and Climate Law Review 405-416, 409; C Symmons, 'Some Problems Relating to the Definition of Insular Features in International Law' (1995) 1(5) Maritime Briefing (Durham, International Boundaries Research Unit) 25-26.

13 For example, during the volcanic activity leading to the formation of Surtsey Island, two other above-surface 'satellite islands' were formed, but were subsequently eroded such that they lie 20-40 m below the ocean surface. See S Friðriksson, Surtsey: Evolution of Life on a Volcanic Island (London, 1975) 29-30; Symmons, above (n 12), 26.

14 C MacLaren, 'The Glacial Theory of Professor Agassiz of Neuchatel' (1842) 42 American Journal of Science $346-365$.

15 CV Murray-Wallace and CD Woodroffe, Quaternary Sea-Level Changes (Cambridge University Press, 2013) 1-38.

16 K Rogers and CH Schofield, 'Responding to Changing Coasts: The Need for Fixed and Flexible Limits and Boundaries in the Face of Sea Level Rise' in J Kraska and C Esposito (eds), Ocean Law and Policy: Twenty Years of Development under UNCLOS (Martinus Nijhoff, 2016) 419-445, 437. 
It is now widely acknowledged that global mean sea levels are rising and doing so more swiftly than initially anticipated. Indeed, it is striking to the contemporary observer how projections of sea level rise have escalated over time. For example, in 199o Freestone noted that the Intergovernmental Panel on Climate Change (IPCC) provided a 'best estimate' of sea level rise of $18 \mathrm{~cm}$ by 2030 primarily attributed to ocean warming and the melting of glaciers. ${ }^{17}$ The IPCC's projections have subsequently risen such that by the time of its, at the time of writing, most recent report, Assessment Report 5 (AR5), this figure had escalated to a projected rise in sea level of up to $98 \mathrm{~cm}$ by $2100 .{ }^{18}$ In making this projection the IPCC acknowledged, however, that changes in sea level exhibit substantial spatial and temporal variability, indicating that sea level changes would likely feature 'a strong regional pattern, with some places experiencing significant deviations of local and regional sea level change from the global mean change.'19

These changing projections are reflective of much improved knowledge of the way in which the rate of sea level rise has accelerated into the $21^{\text {st }}$ century, ${ }^{20}$ as well as the complexities and uncertainties related to sea level rise. In particular, enhanced understanding of the contribution of grounded ice to rising sea levels led to substantial increases in projections for global sea level rise in AR5 as compared with earlier assessments. It is, however, important to note that while scientific understanding of sea level rise has advanced considerably, major uncertainties remain. Potential contributions to sea level rise from the cryosphere remain a crucial area of concern. In particular, the melting of the major land-based ice sheets such as those of Antarctica and Greenland has the potential to result in many metres of sea level rise. Thus, even relatively moderate melting of such huge bodies of land-based ice would still have profound impacts on global sea level. ${ }^{21}$ As a result, these ice sheets have been termed one of the major climate 'wild cards', in the sense that significant uncertainties persist concerning the magnitude and rate of contribution to sea level rise from grounded ice sheets. ${ }^{22}$

\footnotetext{
17 See Freestone, above ( $\mathrm{n}$ 4), 109.

18 See IPCC, above (n 1), 1137-1205.

19 Ibid 1140.

$20 \quad$ Ibid 11.

21 For example, it has been suggested that accelerated melting of Antarctic ice sheets could lead to sea level rise of twice that projected by the IPCC by 210o. See, for example, RM DeConto and D Pollard, 'Contribution of Antarctica to Past and Future Sea-level Rise' (2016) 531 Nature 591.

22 See G Walker and D King, The Hot Topic: How to Tackle Global Warming and Still Keep the Lights On, (Bloomsbury, 2008) 71-72, 75-80. See also, IPCC above (n 1), 1205.
} 
In its 2018 Special Report on Global Warming of $1.5^{\circ} \mathrm{C}$, the IPCC notes significant advances in the literature since AR5, including the development of structural equation models (SEM) into 'a broader emulation-based approach' partially based on the outcomes of 'more detailed, process-based modelling.'. ${ }^{23}$ This report suggests, with medium confidence, that global mean sea level (GMSL) will rise 'about $0.1 \mathrm{~m}$ less by the end of the century in a $1.5^{\circ} \mathrm{C}$ compared to a $2^{\circ} \mathrm{C}$ warmer world. While this 10 centimetre difference in sea level rise may seem inconsequential, the report estimates that even this seemingly slight increase would mean up to 10.4 million more people being exposed to the threat of sea level rise than would otherwise be the case. ${ }^{24}$ The Special Report also notes that recent literature 'strongly supports' the assessment that sea level rise will continue well beyond 2100.25

This message has been strongly reinforced by the IPCC's, at the time of writing, latest Special Report on The Ocean and Cryosphere in a Changing Climate. ${ }^{26}$ This Special Report estimates that the low-lying coastal zone, defined as land areas less than 10 metres above sea level, are home to approximately 680 million people and that this figure is projected to rise to over one billion by $2050 .{ }^{27}$ Further, the Special Report found, with very high confidence, that the acceleration in global mean sea level rise detected in recent decades was due to 'increasing rates of loss from the Greenland and Antarctic ice sheets' together with continued glacier ice mass loss and ocean thermal expansion. ${ }^{28}$ The Special Report is explicit in asserting high to very high risks are approached for vulnerable communities in coral reef environments, urban atoll islands and low-lying Arctic locations from sea level rise well before the end of this century in the case of high emissions scenarios.' ${ }^{29}$

The United Nations Convention on the Law of the Sea (LOSC) ${ }^{30}$ provides for a zonal system for maritime jurisdiction whereby the outer limits of maritime zones are predominantly delineated on the basis of distance measurements

\footnotetext{
23 IPCC, Global Warming of $1.5^{\circ} \mathrm{C}$, Special Report (8 October 2018), chapter 3, 51, http://www. ipcc.ch/report/sr15; accessed 27 June 2019.

24 Ibid 94.

25 Ibid 53 .

26 IPCC, The Ocean and Cryosphere in a Changing Climate, Special Report, Summary for Policymakers (2019) 32, https://www.ipcc.ch/srocc/home/; accessed 27 June 2019.

27 Ibid 3.

28 Ibid 10.

$29 \quad$ Ibid 32.

$30 \quad$ Adopted 1o December 1982, in force 16 November 1994, 1833 UNTS 3 (LOSC).
} 
from baselines along the coast. Thus, the limits of the territorial sea, contiguous zone and exclusive economic zone (EEZ) are all defined by reference to distance measurements. That is, to maximum distances of 12 nautical miles $(\mathrm{nm}),{ }^{31} 24 \mathrm{~nm}^{32}$ and $200 \mathrm{~nm}^{33}$ respectively.

The delineation of outer continental shelf limits where the coastal State is located on a broad continental margin which exceeds $200 \mathrm{~nm}$ from baselines along the coast ${ }^{34}$ is a more challenging endeavour as such limits are not determined solely by reference to a distance formula. In keeping with the complex series of criteria laid down in Article 76 of the Convention, coastal States are required to formulate a submission of information to the scientific and technical body created by the Convention, the Commission on the Limits on the Continental Shelf (CLCS). ${ }^{35}$ This submission necessarily comprises information related to the morphology of the continental margin in question as well as its geological characteristics. ${ }^{36}$ Although apparently convoluted, as well as expensive in terms of the data-gathering requirements inherent in formulating a submission to the CLCS, this process does provide for definable outer continental shelf limits - something that McDorman has observed represents 'the real achievement' of Article $76 .{ }^{37}$ This represents a major step forward as compared to the uncertain scenario under the 1958 Convention on the Continental Shelf. ${ }^{38}$ Moreover, whilst geomorphological and geological factors are crucial to establishing rights to continental shelf areas seawards of $200 \mathrm{~nm}$ from the

31 Ibid Arts 3, 4. It should be noted that the correct abbreviation for nautical miles is 'M'. However, ' $\mathrm{nm}$ ' is widely used and will be employed in this chapter.

$32 \quad$ Ibid Art 33.

33 Ibid Art 57.

34 Where the outer edge of the natural prolongation of the continental shelf is less than $200 \mathrm{~nm}$ from the coastal baseline, then the outer limit of the shelf may extend to $200 \mathrm{~nm}$ from the baseline (LOSC, ibid Art 76(1)).

35 The Commission is a body consisting of 21 scientists. Importantly, the Commission is not a legal body and it does not therefore adjudicate on submissions. Instead, the CLCS plays, or was intended to play, a technical role, evaluating whether coastal States through their submissions have fulfilled the requirements of Article 76. On the basis of this assessment, the CLCS makes 'recommendations' to the coastal State on the basis of which the coastal State can establish limits that are 'final and binding' (LOsC, ibid Art $76(8)$ ).

$36 \quad$ Losc, ibid Art 76.

37 See TL McDorman, "The Role of the Commission on the Limits of the Continental Shelf: A Technical Body in a Political World' (2002) 17(3) International Journal of Marine and Coastal Law 301-324, 307.

38 Article 1 of the Convention on the Continental Shelf of 1958 defined the continental shelf as 'the seabed and subsoil of the submarine areas adjacent to the coast but outside the area of the Territorial Sea to a depth of 200 metres', 'or to a depth beyond that limit where exploitation of resources was possible'. See Convention on the Continental Shelf, adopted 29 April 1958, in force 10 June 1964, 499 UNTS 311. 
coast, distance-based measurements from baselines along the coast, notably the 200 and $350 \mathrm{~nm}$ lines, remain important criteria. ${ }^{39}$

Agreement on this spatial framework for claims to maritime jurisdiction was a major achievement of LosC, especially in light of the uncertainty that prevailed previously. The foundation of the system of distance-limited maritime zones established under LOSC is, however, the baselines along the coast from which these zones are measured. These baselines provide the essential 'starting line' for the measurement of maritime claims. This zonal system of maritime claims was established in an era when global sea levels were considered to be broadly stable, leading to the general assumption that the coasts providing baselines as a basis for measuring maritime claims were likewise generally stable save for the dynamism of the coast as a consequence of natural forces as noted above.

Freestone, demonstrating his laudable and enduring penchant for interdisciplinary research, delivered a paper in collaboration with physical geographer John Pethick to an expert workshop of the IPCC ahead of its first report being issued in $1990 .{ }^{40}$ In this paper, Freestone and Pethick observed that maritime limits and boundaries are 'defined on the assumption of a stationary coastline', a view stemming from ' $[\mathrm{t}]$ he relative stability of sea level over the past few hundred years' leading to 'a belief in the permanence of the coastlines of the world'. ${ }^{41}$ This understanding informed, or rather misinformed, the drafting of LOSC. As Freestone has observed, '[a]t the time of negotiation of the Law of the Sea regime there was no widespread recognition of the possible problems of sea level rise. 42

From the late 1980 s it became increasingly clear that the assumption that coastlines were generally stable was seriously misplaced. Freestone was among a triumvirate of distinguished legal commentators who made influential contributions that served to identify the key legal implications of global sea level rise and explored the contours of the challenges arising. ${ }^{43}$ In particular, these

39 In particular, geodetically robust distance measurements are required to delineate the $200 \mathrm{~nm}$ limit of the EEZ seawards of which the outer continental shelf is located (LOSC, above (n 30), Art 76(1)). Additionally, one of the two options for delineating the maximum limit of the continental shelf is a distance of $35^{\circ} \mathrm{nm}$ from relevant baselines, the other being $100 \mathrm{~nm}$ from the 2,500 metre isobaths (LOSC, ibid Art 76(5)).

40 See Freestone and Pethick 199o, above (n 4), 237-256.

41 Ibid 238, 241.

42 See Freestone, above ( $(n)$ ), 114.

43 See, in particular, Freestone, above (n 4); AнA Soons, 'The Effects of a Rising Sea Level on Maritime Limits and Boundaries' (1990) 32(2) Netherlands International Law Review 207-232; DD Caron, 'When Law Makes Climate Change Worse: Rethinking the Law of Baselines in light of Rising Sea Level' (1990) 17 Ecology Law Quarterly 621-653. 
authors highlighted not only the threat posed by sea level rise in terms of the inundation of land territory, including environmentally sensitive and valuable coastal areas, but also the threat this poses to the location of baselines along the coast with potential consequences for the outer limits of maritime zones dependent on them.

\section{$5 \quad$ Ambulatory Baselines and Shifting Limits}

Baselines along the coast define the land/sea interface. This distinction between, essentially, where the land ends and the sea begins, is crucial because claims to maritime jurisdiction are dependent on sovereignty over land territory in keeping with the longstanding legal axiom that the land dominates the sea'. The interface between land territory and ocean spaces then becomes significant as the land dominates the sea 'by the intermediary of the coastal front' 44 In legal terms the land/sea interface is provided by what are often termed 'territorial sea baselines' provide the 'starting line' for the measurement of the limits of maritime claims and, despite their name, these baselines are fundamental to the projection of all maritime zones offshore and the delineation of their outer limits.

Article 5 of LOSC provides that the 'normal' baseline is the 'low-water line along the coast as marked on large-scale charts officially recognized by the coastal State'. Such normal baselines, as the name implies, are the default and predominant type of baseline globally. Further, although the Convention provides for a variety of baselines other than normal baselines to be constructed along the coast, ${ }^{45}$ these alternative types of baselines need to start and finish, that is, be connected or anchored to points on the low-water line ${ }^{46}$ such that each system of baselines is 'closed'. 47

44 P Weil, The Law of Maritime Delimitation-Reflections (Grotius Press, 1989) 50. See also North Sea Continental Shelf (Federal Republic of Germany/Denmark; Federal Republic of Germany/Netherlands). Judgment (1969) ICJ Reports , p 3, para.96.

45 Namely straight baselines (LOSC, above (n 30), Art 7), river closing lines (Art 9), bay closing lines (Art 10) and in respect of archipelagic States (Art 47).

46 See Losc, ibid Arts 7, 9, 10, 47; see also Anglo-Norwegian Fisheries (United Kingdom v Norway), Judgment, (1951) ICJ Reports, p 116, 128-129.

47 The UN's Group of Technical Experts on Baselines indicated that, for straight baselines, for example, this meant that 'whether the baselines are drawn along the coast of an island or of the mainland, the system must start and finish on or above the low water line' and that where straight baselines were drawn connecting a fringe of islands 'all the intermediate basepoints must be located on or above the low water line'. See United Nations, Baselines: An Examination of the Relevant Provisions of the United Nations Convention on the Law of the Sea (Office for Ocean Affairs and the Law of the Sea, United Nations, 1989) 23. 
As normal baselines are coincident with the low-water line, this means that coastlines and low-water lines have been viewed as being able to move or 'ambulate' over time as the coastline changes as a result of deposition and erosion as well as other natural processes as noted above. ${ }^{48}$ The 'knock-on' consequence of changing normal baselines is that the outer limits of claimed maritime zones that are measured from such baselines are also likely to shift and change.

The traditional understanding that normal baselines are ambulatory was one also reached by the ILA Committee on Baselines and the International Law of the Sea ${ }^{49}$ This interpretation necessarily means that the outer limits of maritime claims measured from such baselines are also susceptible to change and are therefore potentially malleable, changeable and uncertain. Such a view appears to run counter to the longstanding desire of the international community for certainty and stability in the definition of international limits and boundaries. ${ }^{50}$ The latter trend is clearly evident with respect to the delimitation and demarcation of international boundaries on land for the sake of clarity over sovereignty and thus international peace and security. The desire for clarity over the extent of coastal State jurisdiction is also illustrated by the development of the zonal framework of maritime claims provided for under LOSC whereby zones are predominantly defined by set distances from baselines along the coast.

Here an important distinction can be made between the unilaterally declared outer limits to maritime zones and maritime boundaries. Freestone has been clear and consistent in his view that delimited maritime boundaries are not subject to change, asserting in the early 199os, '[m] aritime boundaries, once made, belong to that class of treaty the validity of which is not affected by 'subsequent fundamental change of circumstances' under the Vienna Convention on the Law of Treaties 1969 (Article 62)(2)(a)). ${ }^{51}$ In contrast, the unilaterally defined outer limits to maritime claims, predominantly defined by distance measurements from baselines along the coast, could shift as the

48 MW Reed, Shore and Sea Boundaries: The Development of International Maritime Boundary Principles through United States Practice (US Government Printing Office, 2000) 185.

49 International Law Association, Sofia Conference (2012), Committee on Baselines under the International Law of the Sea Report, 31.

50 As Jennings observed 'stability of territorial situations' is a 'fundamental interest ... from the point of view of order and peace'. See RY Jennings, The Acquisition of Territory in International Law (Manchester University Press, 1963) 24. See also, MN Shaw, 'The Heritage of States: The Principle of Uti Possidetis Juris Today' (1996) 67(1) British Yearbook of International Law 75-154, 81-97; SN Lalonde, Determining Boundaries in a Conflicted World: The Role of Uti Possidetis (McGill-Queen's University Press, 2002) 138-161.

See Freestone, above (n 4), 114. See also, Freestone and Pethick 1994, above (n 4), 77-78. 
location of the baseline changes. ${ }^{52}$ Similarly, the course of undelimited, that is yet to be agreed, maritime boundaries could be influenced as changes in the baselines from which they are constructed occur. ${ }^{53}$

That normal baselines and thus the outer limits of maritime zones are susceptible to change means that sea level rise means that coastal States are faced with the twin threats of losing both inundated land territory and areas of their maritime claims also and therefore rights over valuable living and non-living marine resources therein.

In this context, two caveats should be borne in mind. First, the outer limits of maritime claims are dependent on specific basepoints located on a coastal State's baseline and not the baseline in its entirety. This is because the outer limits to maritime claims specified by a particular distance, be it 12, 24 of $200 \mathrm{~nm}$, are commonly constructed through the 'envelope of arcs' method which is reliant on the outermost critical basepoints along the baseline with a diminishing number of basepoints required to construct the outer limits of broader maritime zones. ${ }^{54}$ The outer limits to maritime claims will therefore only shift in location if the critical basepoints controlling parts of the envelope of arcs are impacted. Second, that while it is reasonable to suggest that rising sea levels will in all probability lead to recessions inland in the position of normal baselines, there are inherent uncertainties and complexities concerning how sea level rise will impact specific coasts and coastal ecosystems. Rather than simply 'marching up the contours', complex interactions and feedbacks occur between changing sea level and the shape and elevation of the land (as

52 As noted above, the outer limits of the territorial sea, contiguous zone and EEZ are defined as being 12, 24 and $200 \mathrm{~nm}$ from the nearest point on the baselines along the coast (LOSC, above (n 30), Arts 4, 33(2), 57). Further distance measurements from baselines along the coast, notably 200 and $350 \mathrm{~nm}$ limits, remain important components in delineating the outer limits of the continental shelf where is exceeds $200 \mathrm{~nm}$ from baselines along the coast (see Section 4 above).

53 This is the case if such delimitations are based on equidistance lines that are constructed from basepoints located on baselines along the coast. This is a not an unreasonable assumption given both the enduring popularity of this approach to maritime delimitation in State practice and the emergence of a three-stage approach to the maritime delimitation in the jurisprudence, the first stage of which involves the construction of a provisional delimitation line based on equidistance. See JRV Prescott and CH Schofield, Maritime Political Boundaries of the World (Martinus Nijhoff, 2005) 238-239; see also the Case Concerning Maritime Delimitation in the Black Sea (Romania v Ukraine), Judgment, (2009) ICJ Reports, p 61, para 161.

$54 \mathrm{CM}$ Carleton and $\mathrm{CH}$ Schofield, 'Developments in the Technical Determination of Maritime Space: Charts, Datums, Baselines, Maritime Zones and Limits' (2001) 3(3) Maritime Briefing (Durham, International Boundaries Research Unit) 62. 
was alluded to above) resulting in changes to relative sea level. ${ }^{55}$ This suggests that sea level rise does not necessarily automatically translate into retreat in the location of low-water lines in a straightforward manner.

Freestone and Pethick were already well aware of this in their advice to the IPCC in the late 1980s, describing the coast as a 'dynamic landform' whose position is predominantly dependent on 'a form of quasi-equilibrium with its wave and current environment'.56 This means that when sea levels change, the coastline will tend to respond both vertically in terms of its profile and horizontally, notably through longshore sediment distribution. ${ }^{57}$ Freestone also noted the threat that low-lying islands 'disappear entirely' or become uninhabitable such that they would be transformed into 'rocks' within the meaning of LOSC, Article 121(3) and thereby lose 'entitlement to maritime zones previously established' ${ }^{58}$ Thus, despite the above-mentioned caveats, there is little doubt that sea level rise has the potential to significantly alter the 'quasi-equilibrium' fundamental to the location of the coast, leading to retreating and disappearing coasts and islands and consequently significant threats to the extent of national maritime jurisdictional claims, particularly those of States possessing low elevation coasts and low-lying islands.

\section{$6 \quad$ Response Options}

Some of Freestone's pioneering early work on the implications of sea level rise relates to his nuanced, critical evaluation of the options for States facing the challenges posed by sea level rise. These contributions note the potential application of both active and passive policy options, characterized as a 'bulkhead policy' aimed at protecting threatened coastline and the alternative of leaving coasts to change and reach a new equilibrium in response to a changing sea level. ${ }^{59}$

Freestone and Pethick were conscious of the drawbacks often associated with the construction of physical sea defences designed to arrest coastal changes, including the costs of construction and maintenance involved. ${ }^{60}$ Given the often

55 See Rogers and Schofield, above (n 16).

$5^{6}$ Freestone and Pethick 1990, above (n 4), 242.

57 Ibid 242-243.

$5^{8}$ See Freestone and Pethick 1994, above (n 4), 76; see also, Freestone, above (n 4), 12-113; Soons, above (n 43), 207, 223-225.

59 Freestone and Pethick 1990, above (n 4), 247-249.

6o Ibid 247 . 
remote locations and lengthy coastlines of many developing States, especially small island developing States, this response option must be considered to be unrealistic. The authors were similarly well aware of the generally 'deleterious results' of the construction of hard coastal engineering structures including the likely impacts of such interference in natural processes particularly for other parts of the coast whereby 'cessation of natural erosional processes in one area of the coast means that adjoining areas of the coast will be deprived of their sediment supply' ${ }^{61}$ Further, they highlighted possible trans-boundary consequences leading to potential international legal consequences. ${ }^{62}$ Associated concerns relating to the radical implications of coastal defences for ecologically valuable coastal habitats starved of sediment supply essential to their continued existence were also raised and the international obligations of coastal States to protect such areas highlighted. ${ }^{63}$ At the same time, these authors were conscious of the politically unpalatable nature of a totally passive 'do nothing' option which, while allowing the coast to achieve fresh equilibrium with changing sea levels, would also essentially lead to the abandonment of low-lying areas to rising seas. ${ }^{64}$

Freestone and Pethick were similarly cognisant that rising sea levels would necessitate the continuous updating of charts, again categorized as an active option, with the passive option of 'leaving charts alone' in order to preserve existing maritime claims, while avoiding the 'politically undesirable' option of 'the unilateral abrogation of existing maritime areas', could be 'extremely hazardous'.65 This is because the primary purpose of a nautical chart is as an aid for safety of navigation so it is critical that such charts provide as up to date and accurate depiction of the coast and other potential hazards to navigation as is practicable. The authors did posit that there could be a 'widespread evolution of baseline maps' designed to show the baseline for maritime jurisdictional rather than navigational purposes, but cautioned that this could give rise to excessive claims and 'exacerbate this divisive tendency'. 66

61 Freestone and Pethick 1994, above (n 4), 83-84.

62 Freestone and Pethick 199o, above (n 4), 243-245. See also Freestone and Pethick 1994, above (n 4), 83-84. These authors did not, however, rule out more environmentally sensitive 'soft engineering' approaches aimed at delivering 'coastal protection using natural systems'. Ibid 85 .

63 Notably obligations are found under the Convention on Wetlands of International Importance especially as Waterfowl Habitat (Ramsar Convention), adopted 2 February 1971, in force 21 December 1975, 996 UnTs 245. See Freestone and Pethick 1990 above (n 4) 246; see also, Freestone 199o, above (n 4), 119-122; Freestone and Pethick 1994, above (n 4), $86-87$.

64 Freestone and Pethick 1990, above (n 4), 249-250.

65 Ibid 241.

66 Ibid. 
In fact, there is emerging practice of some coastal States that accords with the 'baseline maps' approach, albeit through the designation of the location of baselines, limits and boundaries through geographic coordinates rather than maps. This practice involves the declaring and apparently fixing of baselines of all types including normal baselines as well as the location of the outer limits of maritime zones defined from them. In keeping with his willingness to work collaboratively and across disciplinary boundaries, Freestone and the present author have written on the practice of the Pacific Island States in relation to their maritime claims and boundaries against the context of sea level rise. ${ }^{67}$ Perhaps the best recent example of this type of approach is provided by the Republic of the Marshall Islands which in 2016 passed a Maritime Zones Declaration Act ${ }^{68}$ and Declaration of 'Baselines and Outer Zone Limits'. The latter document, which is over 450 pages long, provides a remarkably detailed definition of the location not only of the baselines of the Marshall Islands and agreed maritime boundaries with neighbouring States, but the outer limits of its maritime zones defined through geographical coordinates and supporting illustrative maps. ${ }^{69}$

This Declaration and analogous practice within the Pacific region are indicative of an emerging pattern of practice in the region whereby States are unilaterally declaring and publicizing their maritime jurisdictional baselines, limits and boundaries. ${ }^{70}$ While this practice of clarifying the limits of maritime jurisdiction clearly has maritime surveillance and enforcement benefits, it also has a sea level rise dimension with the objective of preserving existing maritime zones, regardless of future coastal changes as a consequence of sea level rise. This aim is made explicit in regional strategies and declarations such as the Framework for a Pacific Oceanscape, Action $1 B$ regarding a 'Regional Effort to Fix Baselines and Maritime Boundaries to Ensure the Impact of Climate

67 See, for example, D Freestone and CH Schofield, 'Securing Ocean Spaces for the Future? The Initiative of Pacific sids to Develop Regional Practice Concerning Baselines and Maritime Zone Limits' (2019) 33(1) Ocean Yearbook 58-89; D Freestone and CH Schofield, 'Islands Awash Amidst Rising Seas?: Sea Level Rise and Insular Status under the Law of the Sea' (2019) 34 International Journal of Marine and Coastal Law 391-414.

68 Act No 13 of 2016, https://www.un.org/Depts/los/LEGISLATIONANDTREATIES/ PDFFILES/DEPOSIT/mhl_mzn12O_2016_2.pdf; accessed 27 June 2019.

69 See D Freestone and CH Schofield, 'Republic of the Marshall Islands: 2016 Maritime Zones Declaration Act: Drawing Lines in the Sea' (2016) 31 International Journal of Marine and Coastal Law $720-746$.

70 Ibid. On the efforts of the Pacific island States to redefine their baselines, delineate the limits to their maritime zones and delimit their maritime boundaries, see R Frost et al., 'Redrawing the Map of the Pacific', (2018) 95 Marine Policy 302-310, 302-303 and 306-309. 
Change and Sea Level Rise Does Not Result in Reduced Jurisdiction of PICTs', ${ }^{71}$ states:

Once the maritime boundaries are legally established, the implications of climate change, sea level rise and environmental change on the highly vulnerable baselines that delimit the maritime zones of Pacific Island Countries and Territories should be addressed. This could be a united regional effort that establishes baselines and maritime zones so that areas could not be challenged and reduced due to climate change and sea level rise. ${ }^{72}$

\section{7 \\ The Conclusions of the ILA Committee on International Law and Sea Level Rise}

Continuing his longstanding interest in sea level rise and its impacts and implications for the development of the international law of the sea, Freestone has served as co-rapporteur for the ILA Committee on International Law and Sea Level Rise since its inception in 2012. This Committee was established at the urging of the ILA Committee on Baselines and the International Law of the Sea. ${ }^{73}$ The mandate of this new Committee was to study the possible impacts of sea level rise and the implications under international law of the partial and complete inundation of State territory, or depopulation thereof, in particular of small island and low-lying States; and to develop proposals for the progressive development of international law in relation to the possible loss of all or of parts of State territory and maritime zones due to sea level rise, including the impacts on statehood, nationality, and human rights. ${ }^{74}$

71 See C Pratt and H Govan, Our Sea of Islands, Our Livelihoods, Our Oceania. Framework for A Pacific Oceanscape: A Catalyst for Implementation of Ocean Policy (Pacific Islands Forum Secretariat, November 2010), http://www.forumsec.org/wp-content/uploads/2018/o3/ Framework-for-a-Pacific-Oceanscape-2010.pdf; accessed 27 June 2019.

$72 \operatorname{Ibid} 58$.

73 CG Lathrop, JA Roach and DR Rothwell (eds), Baselines under the International Law of the Sea: Reports of the International Law Association Committee on Baselines under the International Law of the Sea, Brill Research Perspectives on the Law of the Sea (Brill, 2019) 62 .

74 Ibid. See also, D Vidas, D Freestone, and J McAdam, 'International Law and Sea Level Rise: The New ILA Committee' (2015) 21 International Law Students' Association (ILSA) Journal of International and Comparative Law 397-408; Freestone, Vidas and Torres Camprubí, above (n 3$)$. 
Freestone, in his co-rapporteur role, was primarily responsible for law of the sea aspects of the Committee's mandate. The Committee reviewed the causes and consequences of sea level rise for baselines and claims to maritime jurisdiction and delivered its second Report at the 78th Conference of the International Law Association in Sydney in August 2018. ${ }^{75}$ In particular, the Committee highlighted the deep inequity that it is some of the least developed low elevation and small island States that have contributed the least to the greenhouse gas emissions causing anthropogenic climate change, which are threatened with catastrophic impacts to their territorial extent, scope of their maritime claims and, ultimately, their statehood in the case of complete inundation and/or depopulation. The need to preserve the integrity of existing maritime claims and boundaries was also recognized for the sake of maintaining international peace and security.

In considering options whereby coastal and island States may be enabled in maintaining their maritime entitlements notwithstanding changes brought about by sea level rise, the Committee reviewed ways in which the international law of the sea might be progressively developed [de lege ferenda.${ }^{76}$ The significant legal and political challenges associated with such proposals were also acknowledged. ${ }^{77}$ The potential emergence of a new rule of customary international law was also discussed. ${ }^{78}$ Ultimately, the Committee, while noting the range of options available to States that might result in a change to the international law of the sea in response to the threats posed by sea level rise,

75 See ILA, Sydney Conference (2018), Committee on International Law and Sea Level Rise Report. ILA Committee reports are available at https://www.ila-hq.org/index.php/ committees.

76 These options included the development of customary international law, a protocol to the UN Framework Convention on Climate Change, utilization of the amendment provisions of the LOSC, a decision of the Meeting of the State Parties to the LOSC (SPLOS), a diplomatic conference open also for States non-Parties to the LOSC, or an agreement adopted by the UN General Assembly after negotiation in its subsidiary bodies or informal consultations and are discussed in both papers by Freestone and Schofield (2019) above (n 67).

77 Notably in relation to the complexities associated with employing the amendment provisions of LOSC at Articles 311-316. See, for example, D Freestone and AG Oude Elferink, 'Flexibility and Innovation in the Law of the Sea: Will the Los Convention Amendment Procedures Ever Be Used?' in AG Oude Elferink (ed.), Stability and Change in the Law of the Sea: The Role of the LOS Convention (Nijhoff, 2005) 163-216.

78 These discussions were informed in particular by the deliberations of the International Law Commission relating to 'subsequent practice' in relation to the interpretation of treaties under the Vienna Convention on the Law of Treaties. See United Nations General Assembly, Report of the International Law Commission: Sixty-eighth session (2 May-1oJune and 4July-12 August 2016), UN Doc A/71/10, Chapter VI, 121. 
did not propose a preferred course of action. Instead, the Committee's 2018 Report yielded an ILA Resolution. This Resolution noted evidence of emerging State practice, particularly in the South Pacific region regarding the intent of island States to maintain the baselines and limits of their current maritime claims 'notwithstanding physical coastline changes brought about by sea level rise', ${ }^{\prime 9}$ and endorsing the Committee's proposal that

on the grounds of legal certainty and stability, provided that the baselines and the outer limits of maritime zones of a coastal or an archipelagic State have been properly determined in accordance with the 1982 Law of the Sea Convention, these baselines and limits should not be required to be recalculated should sea level change affect the geographical reality of the coastline. ${ }^{80}$

The Resolution also endorsed the Committee's proposal that

the interpretation of the 1982 Law of the Sea Convention in relation to the ability of coastal and archipelagic States to maintain their existing lawful maritime entitlements should apply equally to maritime areas delimited by international agreement or by decisions of international courts or arbitral tribunals. ${ }^{81}$

The Resolution further confirmed that

the Committee's recommendations regarding the maintenance of existing maritime entitlements are conditional upon the coastal State's existing maritime claims having been made in compliance with the requirements of the 1982 Law of the Sea Convention and duly published or notified to the Secretary-General of the United Nations as required by the relevant provisions of the Convention, prior to physical coastline changes brought about by sea level rise. ${ }^{82}$

Through the Resolution, the Secretary-General of the ILA was requested to forward the Resolution to the Secretary-General of the United Nations requesting

79 International Law Association Resolution 5/2018, http://www.ila-hq.org/images/ILA/ Resolutions/ILAResolution_5_2018_SeaLevelRise.pdf; accessed 27 June 2019.

8 o Ibid.

81 Ibid.

82 Ibid. 
that he bring it to the attention of States Parties to LOSC, other interested States and the International Law Commission, which has since formed its own openended Study Group on sea level rise in relation to international law, as well as the Registrars of the International Court of Justice and the International Tribunal on the Law of the Sea as well as the Secretary-General of the Permanent Court of Arbitration. The objective of publicizing the Resolution in this way was to share its deliberations and recommendations with a wider audience as part of the process of furthering the progressive development of the international law of the sea in the face of the significant and escalating threats posed by sea level rise.

Options for Maintaining Existing Maritime Claims

Characteristically, Freestone has offered critical yet constructive analysis, teasing out the pros and cons of some of the key options for the development of the law of the sea to meet the challenge of sea level rise. In order to maintain existing maritime claims one or both of two things need to occur. That is the fixing of baselines despite changes to the physical location of the coastline and/or the fixing of maritime limits regardless of changes in the location of baselines from which they are measured. As Freestone has eloquently suggested, these options are fraught with difficult questions. ${ }^{83}$

For instance, if the option of freezing baselines were to be adopted, it could be argued that this would be permitted under Article 5 of the Convention through the adoption of charts or geographical coordinates 'officially recognized by the coastal State' and through the definition of baselines and outer limits of maritime zones through national legislation. ${ }^{84}$ Under this scenario, as the physical coastline retreats but the baselines remain fixed, the intervening waters would be treated as internal waters. Further, the outer limits of existing maritime zones would not be advanced but merely maintained as originally claimed and charted. This, in turn, would mean that coastal States would not be claiming additional areas but merely preserving existing claims to maritime

83 Discussion here is based on D Freestone and CH Schofield, 'Coastal State Responses to Sea Level Rise:Possible Policy Options de legeferenda', Ocean and Climate Change Governance:Integrating Regulatory Initiatives and Closing Governance Gaps, Law of the Sea Institute (LOSI) International Conference hosted by the World Maritime University, Malmö, 14-15 August 2017 (copy on file with the author). See also Freestone and Schofield 2019, above (n 67), 400-404.

84 On the duty to provide due publicity with respect to non-normal or 'artificial' baselines in keeping with LOSC, Article 16(1), see CR Symmons and MW Reed, 'Baseline Publicity and Charting Requirements: An Overlooked Issue in the UN Convention on the Law of the Sea' (2010) 41 Ocean Development and International Law 77-111. 
space. Moreover, this option would serve to protect some of the most vulnerable States from impacts of climate change inspired sea-level rise that they have done little to cause themselves.

Of particular interest here is that there is some judicial support for stabilizing basepoints and thereby fixing associated maritime limits in certain contexts under European Union Law. When the United Kingdom extended its territorial sea from 3 to $12 \mathrm{~nm}$ a number of low-tide elevations fell within the UK's expanded territorial sea and could thus be used as basepoints consistent with LOSC, Article 13 - something that would have excluded Belgian and French fishers from parts of their traditional fishing grounds under the 1964 European Fisheries Convention. ${ }^{85}$ In the resulting UK Baselines Case European Court of Justice ruled that with regard to fisheries zone limits the baselines to be used were those in effect in 1983 when the basic management regulations relating to the EU's Common Fisheries Policy were adopted. ${ }^{86}$ As Long has observed, this means that 'the Court ruled firmly out the international law concept of ambulatory baselines'. ${ }^{87}$

The counterpoint to this is that freezing baselines would create a legal fiction as the physical coast is anticipated to diverge from its existing position. Freezing baselines would also not reflect the traditionally understood ambulatory character of baselines as confirmed by the ILA Committee on Baselines. Arguably this use of an 'imaginary' coast would also mean that the land in effect no longer dominates the sea, contrary to the aforementioned longstanding maxim to that effect. Were charts to be issued with frozen rather than actual baselines depicted on them this would clearly pose safety of navigation concerns as the primary purpose of nautical charts is to act as aids to navigation by providing an accurate depiction of the location of the coast. It is also of significance that charts reflect the location of the baselines so that the mariner approaching the coast can calculate which zone of maritime jurisdiction they are navigating through. As Symmons and Reed have noted, 'without that information, they may unintentionally violate coastal State regulations'. ${ }^{88}$ That said,

85 See R Long, 'Stepping over Maritime Boundaries to Apply New Normative Tools in EU Law and Policy' in M Nordquist and J Norton Moore (eds), Maritime Border Diplomacy (Martinus Nijhoff Publishers, 2012) 213-264, 244-246.

86 See Case C-146/89, Commission v UK, para 27.

87 Long 2012, above (n 85), 244. As a result of this decision, the United Kingdom has two distinct $12 \mathrm{~nm}$ limits around certain features in the south west approaches to the English Channel for different purposes. Ibid 245 . 
specific baseline maps could be issued for the purpose of illustrating jurisdictional baselines, limits and boundaries.

An arguably more attractive alternative option is that lists of coordinates could be provided to define baselines, limits and boundaries. This choice of means to provide due publicity as to the location of baselines, limits and boundaries to the international community has the considerable merit of sidestepping the use of charts or baseline maps, meaning that safety of navigation concerns do not arise. Such lists of coordinates can, nonetheless, be utilized and overlaid on electronic charts, becoming an additional layer of information to inform the mariner. Further, the deposit of digital representations on maritime limits and boundaries with the United Nations Secretary-General via the United Nations Division of Ocean Affairs and the Law of the Sea (DOALOS) is likely be facilitated through innovative new methods in the near future. ${ }^{89}$ This approach has been adopted through a coordinated approach among the Pacific Island States including in the Declaration of the Republic of the Marshall Islands mentioned above. ${ }^{90} \mathrm{~A}$ further consideration is that should baselines retreat inland and coastal State maritime claims recede accordingly, the high seas would necessarily increase in area. Freezing baselines would prevent this expansion of the commons spatially, raising a global public interest concern. ${ }^{91}$

Alternatively, were the outer limits of maritime zones to be fixed, this could be applied to the limits of either the territorial sea and/or the limits of the EEz. The merits of this option include that the baseline would remain ambulatory and would be reflected on nautical charting, thus negating safety of navigation concerns. However, the coastal State would retain defined outer limits of maritime zones and thus existing claims to maritime spaces. The obvious negative aspect of such an option is that as the physical coastline retreats the distance between fixed outer limits and the ambulatory and retreating low-water line

89 Notably through the advent of the proposed IHо S-121, an open-access method of providing digital representation of maritime limits and boundaries. See International Hydrographic Organization, 'S-121 Project Team', https://www.iho.int/mtg_docs/com_wg/ S-10oWG/S-121PT/S-121PT.htm and http://www.s-121.com/w/index.php/Main_Page; both accessed 27 June 2019 .

$90 \quad$ Freestone and Schofield 2016, above (n 69); see also, Frost 2018, above (n 7o).

91 Ambulatory and likely retreating baselines and outer limits to national maritime claims in the context of sea level rise would necessarily mean increased areas of the global ocean subject to the high seas regime and such an expansion in the Commons can in principle be viewed as being in the public interest. A counterpoint is that fixed baselines and/ or limits would deliver greater stability and certainty over the outer limits of maritime claims, which can also be viewed as being in the public interest. 
based normal baselines would necessarily, as it were, stretch and thus exceed the specified maximum breadth limits of $12 \mathrm{~nm}$ for the territorial sea and 20onm for the EEz. Moreover, similar to the option of fixing baselines, the high seas, and thus global commons, would be prevented from expanding, again raising a global public interest issue.

Finally, were both baselines and limits fixed, coastal States would retain their charted outer limits of maritime zones and present claims to maritime spaces. The breadth of claimed maritime zones would accord with those provided for under LOSC provisions and the central purpose of the exercise, that of protecting vulnerable States from the potential impacts of climate change inspired sea level on the extent of their existing maritime entitlements, would be met. However, the fixed baselines would likely not reflect the physical reality of the coast with all the problematic aspects related to this legal fiction noted above, including navigational safety concerns and the potential decoupling of the fundamental concept of land dominating the sea.

\section{$9 \quad$ Towards a New Frontier in the Law of the Sea?}

Since the early 1990s Freestone has consistently advocated both a precautionary and cooperative approach in the face of the threats posed by sea level rise. ${ }^{92}$ He has also emphasized that international law provides opportunities for the development of new rules and principles. ${ }^{93}$ It appears that growing awareness of significant and accelerating sea level rise and its impacts on coastlines and thus the baselines upon which claims to maritime jurisdiction rely means that the international community is poised for such a significant evolution in, or interpretation of, the international law of the sea.

92 See, for example, D Freestone, 'The Precautionary Principle' in R Churchill and D Freestone (eds), International Law and Global Climate Change (Graham and Trotman, 1991) 21-4O; D Freestone and E Hey (eds), The Precautionary Principle and International Law: The Challenge of Implementation (Kluwer Law International, 1996); D Freestone, 'Implementing Precaution Cautiously: The Precautionary Approach in the 1995 Straddling Stocks Agreement' in E Hey (ed.), Developments in International Fisheries Law (Kluwer Law International, 1999) 287-325; D Freestone, 'Caution or Precaution: "A rose by any other name"' (1999) 12 Yearbook of International Environmental Law 25-32; D Freestone, 'The Marine Environment' in JB Wiener, MD Rogers, JK Hammitt and PH Sand (eds), The Reality of Precaution: Comparing Risk Regulation in the US and Europe (RFF Press, 2010) 177-200.

93 See, for example, D Freestone, 'Editorial: Principles Applicable to Modern Oceans Governance' (2008) 23 International Journal of Marine and Coastal Law 385-391. 
If existing baselines and limits, and thus maritime entitlements, of coastal States are to be protected as advocated by the above-mentioned ILA Resolution and consistent with emerging State practice as well as some international jurisprudence, as mentioned above, this presents challenges to traditional interpretations of the law of the sea. In particular, should baselines and limits be fixed yet sea levels rise, then the location of normal baselines coincident with the lowwater line will likely retreat and for some low-elevation coastlines potentially dramatically. This would inevitably lead to the scenario of baselines fixed for the purpose of measuring maritime entitlements diverging from the actual physical location of the coast and thus low-water line dependent normal baselines. Quite apart from the question of the status of the waters overlying this gap between fixed baselines and the physical reality of the shore, such a scenario would seem to run counter to predominantly the concept of the land dominating the sea.

The counterpoint to this is, however, a compelling one. It is now wellestablished in the scientific community that global sea levels are rising and despite the episodic as well as spatially and temporally uneven nature of the phenomenon, they are doing so at an accelerated rate. Consequently, coastlines and therefore baselines consistent with low-water lines along the coast are likely to retreat. If baselines and maritime zone limits are not fixed, therefore, then it is some of the least developed low-elevation coastal States, including numerous small island developing States, that will be most vulnerable. Moreover, the consequences felt would extend not only to potentially severe impacts to the extent of their land territory to the point of their viability as States, but also to the loss of some or all of their existing maritime entitlements.

This would be catastrophic for small island yet large ocean States that are largely dependent on the valuable marine resources within their maritime zones. Arguably this calls for a more flexible, nuanced, interpretation of the relationship between sovereignty over land territory and maritime entitlements over time. Maritime baselines, limits and boundaries could be, and arguably already in some cases have been, fixed on the basis of existing coastlines and in keeping with the provisions of the LOSC. This can be allied to due publicity as to the location of baselines, limits and boundaries being provided to the international community through declarations featuring the use of geographic coordinates rather than nautical charts being lodged with the United Nations Secretary-General via the DOALOs. This represents an excellent way to achieve the preservation of existing entitlements desired by coastal States increasingly threatened by rising seas, yet elegantly circumvent safety of navigation concerns or confusions potentially raised by creating baseline maps or charts for maritime jurisdictional rather than navigational purposes.

Such definition, delineation and delimitation of baselines, outer limits to maritime zones and maritime boundaries would clearly be of benefit to both 
coastal States, mariners and the international community as a whole as this would serve to deliver clarity, certainty and stability in important jurisdictional 'lines in the sea'. It is also difficult to construe such a policy option, essentially aimed at preserving the existing maritime entitlements and rights of vulnerable coastal States, as especially excessive in character. It can also be observed here that the international law of the sea and indeed the LOSC, are capable of gradual, orderly evolution and such changes will be increasingly and urgently needed in an era of climate change impacts such as sea level rise. ${ }^{94}$

Professor Freestone has been, and remains, at the forefront of international legal thinking on these frontier issues of the law of the sea. There is little doubt that he will have a salient role to play in charting the precise mechanisms and procedures through which the progressive developments in the international law of the sea will be achieved.

94 D Freestone and $\mathrm{CH}$ Schofield, 'Options to Protect Coastlines and Secure Maritime Jurisdictional Claims in the Face of Global Sea Level Rise' in M Gerrard and G Wannier (eds), Threatened Island Nations: Legal Implications of Rising Seas and a Changing Climate (Cambridge University Press, 2013) 141-165, 165. 